\title{
Development of Lectora Inspire Learning Media on Short Stories with Ecology Content for Class XI Students of SMA Negeri 1 Percut Sei Tuan
}

\author{
Irma Yani Tarigan ${ }^{1, *}$ Wisman Hadi $^{2}$ Khairil Ansari ${ }^{3}$ \\ ${ }^{1,2,3}$ Indonesian Language and Literature Education Study Program of Postgraduate Scholl of Universitas Negeri \\ Medan, Indonesia 20221 \\ Corresponding author. Email :irma.yani.tarigan@gmail.com
}

\begin{abstract}
This study aims to produce learning media products Lectora inspire on ecologically charged short stories for class XI students of SMA Negeri 1 Percut Sei Tuan, determine the feasibility of Lectora inspire learning media on ecologically charged short stories for class XI students of SMA Negeri 1 Percut Sei Tuan, and its effectiveness the product developed in the form of learning media Lectora inspire on ecologically charged short stories for class XI students of SMA Negeri 1 Percut Sei Tuan. The research method used is a research and development method that refers to the DDD-E model (Decide, Design, Develop, Evaluate). The results showed that: (1) the results of the validation of the material included the feasibility of content obtaining an average of $84,09 \%$ with very good criteria, the feasibility of presenting an average of $83,33 \%$ with very good criteria, and language eligibility getting an average of $86,25 \%$ with very good criteria. The results of the validation of design experts obtained an average of $90.17 \%$ with very good criteria. (2) The results of individual trials obtained an average of $81.25 \%$ with good criteria, small group trials obtained an average of $86.34 \%$ with very good criteria, and limited field trials obtained an average of $90.1 \%$ with very good criteria. (3) The results of the effectiveness of learning media are obtained through student learning outcomes in the pretest and posttest. The average score at the pretest was 70.36 and at the post-test was 82.06.
\end{abstract}

Keywords: Instructional media, lectora inspire, short story text, ecology.

\section{INTRODUCTION}

The use of technology in the learning process has not been fully used by teachers. This is due to the lack of knowledge and skills of teachers about the use of technology to design learning media. This makes teachers only uses learning media such as powerpoint.

The media is less effective because powerpoint cannot present all learning materials [1]. In addition, powerpoint also cannot present learning materials accompanied by animations. Even though the addition of animation can increase student interest in the material being studied. Some of these weaknesses make powerpoint media unable to accommodate students' abilities in writing short stories.

Some of these weaknesses make powerpoint media unable to accommodate students' ability to write short stories. So that more effective learning media is needed, especially during this Covid-19 pandemic which requires online learning. Online learning demands the ability of teachers to package materials into learning media that are easily accessible to students.

There are many alternative learning media that can be used, one of which is lectora inspire. Lectora inspire is software that is used as an alternative to making interactive learning media as well as being used as a learning medium ${ }^{[2]}$. The learning media can be accessed by students anywhere and anytime so that it is more effectively used in online learning during the Covid-19 pandemic, especially in the text-based 2013 Curriculum Indonesian language learning.

One of the texts taught at the high school level in Class XI Curriculum 2013 is the short story text. A short story is a literary work with a word count of around 500-5,000 words and can be read in ten minutes or half an hour ${ }^{[3]}$. Learning to write short stories is important for students, because short stories can be used as a means to imagine and express thoughts. However, based 
on the results of observations, it was found that students were less interested in writing short stories. The learning process that relies only on Indonesian textbooks without any guidance for writing short stories has an impact on learning outcomes that are less than optimal.

Writing short stories starts from events or experiences that have been experienced by students, so it is important to choose a theme that is relevant to the life and environment of students. Most students use Indonesian textbooks as a reference in choosing the theme to be developed. Even though the theme of the short story contained in the textbook is not in accordance with the needs of students. Examples of short stories in Indonesian textbooks contain general themes and are far from the student's environment. So that students still find it difficult to understand the short story text material and it is difficult to communicate their ideas through writing, especially in determining the theme, developing and compiling their ideas in a coherent paragraph. The difficulties experienced by these students resulted in a decrease in students' interest in writing short stories.

Some of the obstacles experienced by students when writing short stories were also reinforced by Umar's opinion which stated that the low interest of students in writing short stories was due to several obstacles such as lack of imagination, use of less varied diction, difficulty determining themes, and less able to develop ideas ${ }^{[4]}$. In connection with the problems above, the researcher proposes an alternative solution, namely using ecological content in writing short stories. According to Endraswara ecology is the study of the relationship between plants, animals, and humans who interact with each other or with their environment ${ }^{[5]}$. Aside from being a content for developing short stories topics, ecology is also something that must receive special attention because environmental damage often occurs.

Ecological content in writing short stories can be realized through themes around environmental problems, the setting of place and time of environmental problems that occur, conflicts that occur between the main character and the environment, and mandates that become solutions to environmental problems that occur. Through texts that contain ecology, learning will be closer to students' lives. So as to increase students' interest in learning to write short stories. Besides being able to increase students' interest in learning, the ecological content in short stories can also increase students' awareness of the environment.

To accommodate ecology in learning to write short stories, learning media is needed that is able to bring the outside world or the environment into the classroom.
Learning to write short stories with ecological content can be packaged in a learning media Lectora inspire which is able to contain environmental problems as inspiration in writing and emphasizes student learning independence.

\section{RESEARCH METHODS}

The type of research in this research is research and development $(\mathrm{R} \& \mathrm{D})$. The development procedure in this study uses the DDD-E (Decide, Design, Develop, Evaluate) multimedia development model ${ }^{[6]}$. The data collection technique in this development research used a questionnaire (questionnaire), namely an expert validation questionnaire and a teacher response questionnaire.

The data analysis technique used is descriptive analysis, which describes the data that has been collected as it is. The data were obtained through expert validation, teacher responses, and student trials. The data is presented in the form of a Likert scale that has been given a score. Then the data were analyzed descriptively quantitatively, namely calculating the percentage of indicators for each category in the developed learning media, with the formula:

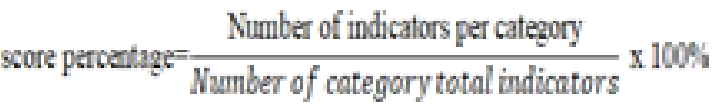

\section{RESULTS AND DISCUSSION}

\subsection{The Process of Developing Lectora Inspire Learning Media on Short Stories with Ecology Content}

The process of developing the learning media Lectora inspire on ecologically charged short stories is carried out in four stages, namely decide, design, develop, and evaluate. At the decide stage, a needs analysis for teachers and students is carried out. Then set the instructional objectives, namely basic competencies, indicators of competency achievement, learning objectives, and the scope of the material in the developed learning media. At the design stage, the outline of the material in the learning media is designed. The develop stage is the stage of developing the outline of the material that has been made in the previous stage into a more complete display of learning media. Furthermore, the evaluate stage is the assessment stage of the learning media that has been developed. The validation assessment was carried out by 2 material experts and 2 design experts, 2 Indonesian language teachers and testing on students. 
Table 1. The Validity of Material Expert

\begin{tabular}{|l|c|}
\hline Component & $\begin{array}{c}\text { Material Expert } \\
\text { Validation Result }\end{array}$ \\
\hline Content eligibility & $84,09 \%$ \\
\hline Serving eligibility & $83,33 \%$ \\
\hline Language eligibility & $86,25 \%$ \\
\hline Average & $84,56 \%$ \\
\hline
\end{tabular}

Table 2. The Validity of Design Expert

\begin{tabular}{|l|c|}
\hline \multicolumn{1}{|c|}{ Component } & \multicolumn{1}{|c|}{$\begin{array}{c}\text { Design Expert } \\
\text { Validation Result }\end{array}$} \\
\hline Writing display & $92,85 \%$ \\
\hline $\begin{array}{l}\text { Image and music } \\
\text { display }\end{array}$ & $92,85 \%$ \\
\hline attractiveness & $87,5 \%$ \\
\hline Cohesiveness & $87,5 \%$ \\
\hline Average & $90,17 \%$ \\
\hline
\end{tabular}

\subsection{Effectiveness of Lectora Inspire Learning Media on Short Stories with Ecology Content}

The effectiveness of the learning media Lectora inspire on ecologically charged short stories is obtained from the results of learning to write ecologically charged short stories. Learning outcomes after using lectora inspire learning media are in the "very good" category with an average score of 82.06 and the average value before using lectora inspire learning media is 70.36 which is in the "good" category. This proves that the effectiveness of the learning media lectora inspire in short stories with ecological content is higher with a difference of 11.70 in value. The ecological content in the text will make it easier for students to develop their ideas. This is in line with the opinion of Satriyani in her research which reveals that the ecological content in the text allows students to more easily learn and enjoy the learning process because they are dealing with topics or problems that come from their environment ${ }^{[7]}$.

\section{CONCLUSION}

The process of developing the learning media lectora inspire on ecologically charged short stories is carried out in four stages, namely decide, design, develop, and evaluate.

\subsection{The Validity of Lectora Inspire Learning Media on Short Stories with Ecology Content}

The validity of the learning media Lectora inspire in the short story text containing ecology was obtained based on the validation results of material experts and design experts. Based on the results of expert validation of the learning media material lectora inspire, the short story text containing ecology is in the very good category with an average of $84.56 \%$ and based on the results of the design expert validation obtained an average of $90.17 \%$ which is in the very good category.

The effectiveness of Lectora inspire learning media on ecologically charged short stories after using lectora inspire learning media is in the "very good" category with an average value of 82.06 .

\section{REFERENCES}

[1] Kamil, Popo Musthofa. Perbedaan Hasil Belajar Siswa Pada Materi Sistem Pencernaan Pada Manusia Dengan Menggunakan Media Power Point Dan Media Torso, Jurnal Bioedusiana, 2008.

[2] Tompo, Basman. Membuat Aplikasi dan Media Pembelajaran Interaktif with Lectora Inspire 16, Penertbit IGI DIY, 2017.

[3] Kosasih, E dan Kurniawan, Endang. 22 JenisJenis Teks \& Strategi Pembelajarannya di SMAMA/SMK, Yrama Widya, 2019.

[4] Umar, Seniwati. Peningkatan Keterampilan Menulis Cerpen dengan Strategi Copy the Master Melalui Media Audiovisual pada Siswa Kelas IXa SMP Negeri 2 Tolitoli. Jurnal Kreatif Tadulako Online Vol. 4 No. 6. 2016.

[5] Endraswara, Suwardi. Sastra Ekologis: Teori dan Praktik Pengkajian, CAPS, 2016.

[6] Tegeh, I Made dkk. Model Penelitian Pengembangan, Graha Ilmu, 2014.

[7] Satriyani, Linggar Dyah, dkk. Penggunaan Teks Bermuatan Pendidikan Ekologi Berbasis Kesenian Lokal Topeng Ireng Sebagai Bahan Ajar Bahasa Indonesia Kelas VIII SMP Negeri 1 Boyolali. Seminar Nasional Inovasi Pembelajaran Bahasa Indonesia di Era Revolusi Industri 4.0, 2020. 